\title{
Natural Right of Blood Descendant-Females of the Founding Ancestors of Bonny Kingdom to Leadership Positions: Spotlight on Queen Kambasa and Legacies of Her Reign
}

\author{
Edward T. Bristol-Alagbariya* \\ Associate Dean \& Senior Multidisciplinary Lecturer, Faculty of Law, University of Port Harcourt, \\ NIGERIA; Affiliate Visiting Fellow, University of Aberdeen, UNITED KINGDOM; and Visiting \\ Research Fellow, Centre for Energy, Petroleum \& Mineral Law and Policy (CEPMLP), Graduate \\ School of Natural Resources Law, Policy \& Management, University of Dundee, Scotland, UNITED \\ KINGDOM \\ * E-mail of the corresponding author: ebristolalagbariya@gmail.com
}

Abstract

This study emanates from a previous work of the Author on 'Natural Law as Bedrock of Good Governance' in Bonny Kingdom. The previous work examined the origin of public sector governance from the beginning of the Kingdom, within the rubrics of the house system. The work established that although the Kingdom's form of traditional government is hierarchical in form, during the era of its Founding Ancestors, decision-making and decision-implementation processes were characteristically the collective affair of its homogeneous founding kindred group. The work demonstrates that the Kingdom's primordial form of governance was public-spirited by nature and thus based on responsible stewardship to its entire people and Kingdom at large. It proves that natural law was the bedrock of the reign of the Founding Fathers, Patriarchs and Premier Monarchs of the Kingdom, namely Ndoli-Okpara, Opuamakuba, Alagbariya and Asimini. That natural law has features, which characterised the reign of the Premier Monarchs; these features include love, truth, goodwill, selflessness, responsible stewardship, integrity, fair-play, sincerity of purpose, transparency, accountability, harmonious and unanimous decision-making and decision-implementation processes, which amounted to partnership in governance, towards the overall good of the people and the Kingdom. The previous work thus qualifies the reign of the Premier Monarchs of the Kingdom as being fundamentally selfless. The work establishes that based on the landmark form of public-spirited leadership of Bonny Kingdom's Premier Monarchs, successive Monarchs of the Kingdom, who assumed Kingship on the basis of natural law and its accompanying natural right of succession to leadership, promoted and practised selfless leadership; this was exemplified by the administration of King Halliday-Awusa. The work arrives at the conclusion that the Founding Ancestors, led by the Premier Monarchs, established an admirable and commendable form of governance that exemplifies how the people and lineages (families or houses) of the Kingdom should relate between and among themselves on the basis of the characteristic features of natural law. It enjoins succeeding generations of the Kingdom, led by its subsequent Monarchs and other members and organs of the apex traditional ruling council, to consolidate on the exemplary leadership qualities of the Premier Monarchs and King Halliday-Awusa, by enhancing and practising traditional government social responsibility (TGSR), towards good traditional governance (GTG) and sustainable community development (SCD) in oil-rich and Christianised Grand Bonny Kingdom. Furthermore, the previous work establishes that natural law-oriented natural right to leadership positions and succession to kingship in primordial Grand Bonny Kingdom was not discriminatory against female blood descendants of the Founding Ancestors of the Kingdom. This gave impetus to Princes Kambasa to desirously and intensively aspire to become a Monarch of the Kingdom. She succeeded her blood-ancestors as Monarch, after the reign of her father, King Edimini. The previous work then remarked that the circumstances of ascension of Queen Kambasa merit to be examined in an independent study, which is capable of contributing to the worldwide knowledge industry; this remark necessitated the present study. Therefore, the aim of this socio-legal and divinely-rooted study is to examine the natural right of blood descendant-females of the Founding Ancestors of Bonny Kingdom to traditional leadership positions, particularly the position of Kingship, using Queen Kambasa as case-study.

Keywords: Natural Law; Natural Right; Succession; Kingship (Amanyanaboship); Bonny Kingdom; Founding Ancestors; Founding Fathers, Patriarchs and Premier Monarchs; Good Public Sector Governance (Good Governance [GG]); Good Traditional Governance (GTG); Traditional Government Social Responsibility (TGSR); Female Blood Descendants; Blood Descendants; Reign; Legacy (Legacies); Queen Kambasa; Queen Amina of Zaria.

DOI: $10.7176 / \mathrm{DCS} / 10-3-09$

Publication date:March $31^{\text {st }} 2020$ 


\section{Introduction}

This study originates from a previous work of the author on natural law as bedrock of good governance in oil-rich Ancient Grand Bonny Kingdom, simply called as Grand Bonny Kingdom or Bonny Kingdom. The previous work explored, examined and discussed the origin of public sector governance from the beginning of the Kingdom, within the rubrics of the house system, by the Founding Ancestors of the Kingdom. The work establishes that although the Kingdom's form of traditional government is hierarchical in nature, during the era of the Founding Ancestors, decision-making and decision-implementation processes were characteristically harmonious and unanimous between and among the homogeneous founding kindred group of the Kingdom. The work demonstrates that the Kingdom's primordial form of governance was public-spirited and thus based on responsible stewardship to the entire people of the Kingdom and the Kingdom as a whole. It proves that the administration of the Founding Fathers, Patriarchs and Premier Monarchs of the Kingdom, namely Ndoli-Okpara, Opuamakuba, Alagbariya and Asimini, may be described as classic form of partnership in governance, towards the overall good of the people and the entire Kingdom. The peculiarity of the reign of the Premier Monarchs demonstrates that natural law, which establishes divine origin of law and rulership (governance) in human society, ${ }^{1}$ was the bedrock of their administration and style of leadership. ${ }^{2}$ Natural law has inherent features such as love, truth, goodwill, selflessness, benevolence, responsible stewardship, humility, such moral (ethical) norms as integrity, fair-play, commitment to duty, sincerity of purpose, transparency, accountability, unanimous decision-making and decisionimplementation processes, which prevail towards public good and the overall wellbeing of society. ${ }^{3}$ The previous work thus characterises the administration of Bonny Kingdom's Premier Monarchs as being fundamentally selfless The work also establishes that based on the landmark form of public-spirited leadership of the Premier Monarchs, their immediate successors, which assumed Kingship on the basis of the natural right to leadership and succession, imbibed and practised selfless leadership; this was exemplified by the administration of King Halliday-Awusa. The work arrives at the conclusion that the Founding Ancestors, led by the Premier Monarchs, established an exemplary form of government, which translates to how the people and lineages (families or houses) of the Kingdom should relate between and among themselves on the basis of the characteristic features of natural law. It enjoins and sensitises succeeding generations of the Kingdom, led by the Monarchs and other members and organs of the apex traditional ruling council of their times, to consolidate on the exemplary leadership qualities of the Premier Monarchs and King Halliday-Awusa, by enhancing and practising traditional government social responsibility (TGSR), towards good traditional governance (GTG) and sustainable community development $(\mathrm{SCD})^{4}$ in oil-rich ${ }^{5}$ and Christianised ${ }^{6}$ Grand Bonny Kingdom.

Remarkably, one of the Monarchs who succeeded her blood-ancestors before the era of King HallidayAwusa was Queen Kambasa. The previous work established that natural law-oriented natural right to leadership positions and succession to kingship in primordial Grand Bonny Kingdom was not discriminatory against female blood descendants of the Founding Ancestors of the Kingdom. Hence, Princess Kambasa passionately and vigorously aspired to become the Kingdom's Monarch. The previous work then remarks that the circumstances of ascension of Queen Kambasa merits to be examined in an independent study, which is capable of contributing to the worldwide knowledge industry; this remark necessitated the present study.

This socio-legal and divinely-centred study will therefore examine the natural right of blood descendantfemales of the Founding Ancestors of Bonny Kingdom to traditional leadership positions, particularly the position of Kingship, using Queen Kambasa as case-study. This is particularly so, considering the primordial equality status of all blood descendants of the Founding Ancestors, regardless of whether they are males or females, which is

${ }^{1}$ C. F. Alford, Narrative, Nature, and the Natural Law: From Aquinas to International Human Rights (Palgrave Macmillan 2010); Stanford Encyclopedia of Philosophy, 'Natural Law Theories' $<$ https://plato.stanford.edu/entries/natural-law-theories/> Accessed 27 March, 2020.

${ }^{2}$ L. Strauss, Natural Right and History (Charles R. Walgreen Foundation Lectures) (University of Chicago Press 1965); J. Finnis, Natural Law \& Natural Rights (Oxford University Press 2011); C. F. Alford (n1).

${ }^{3}$ E. T. Bristol-Alagbariya, Governance Towards Sustainable Development in Nigeria: The Role of Strategic Assessment of Decisions \& Actions (Centre for Energy, Petroleum \& Mineral Law \& Policy [CEPMLP]/Dundee University Press [DUP] 2013), particularly 44-49 and 286; Holy Bible, Philippians 4:8-9, which provides thus: Finally, brethren, whatsoever things are true, whatsoever things are honest, whatsoever things are just, whatsoever things are pure, whatsoever things are lovely, whatsoever things are of good report; if there be any virtue, and if there be any praise, think on these things. those things, which ye have both learned, and received, and heard, and seen in me, do: and the god of peace shall be with you.

${ }^{4}$ E. T. Bristol-Alagbariya, Participation in Petroleum Development: Towards Sustainable Community Development in the Niger Delta (CEPMLP/DUP 2010).

5 The Nation newspaper report captioned 'Amazing story of a rich Island whose people need help' $<$ https://thenationonlineng.net/amazing-story-of-a-rich-island-whose-people-need-help-2/>; Nigeria LNG Limited, 'Host Communities' $<$ http://nlng.com/Our-Company/Pages/Our-Community.aspx $>$; Offshore Technology, Exxon-East Area NGL II

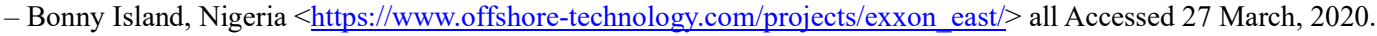

${ }^{6}$ E. J. Alagoa and A. Fombo, A Chronicle of Grand Bonny (Ibadan University Press 1972/Onyoma Research Publications 2001), 24-27. 
protected by law, specifically human rights law, against the prevailing, obvious, improper and unequal status of women with their male counterparts in the realm of Bonny Kingdom's traditional governance. Human rights and other legal instruments, particularly sustainable development (SD)-oriented soft law instruments, such as specific goals of the UN Millennium Development Goals (UN MDGs) and the UN SDGs guarantee gender equity and equality. ${ }^{1}$

\section{Bonny Kingdom}

Bonny Kingdom (variously called Ancient Grand Bonny Kingdom and Grand Bonny Kingdom: Ancient Ibani Nation: 'Ibanise') is located in the eastern Niger Delta, along the Atlantic coast, in the Bonny Local Government Area (OLGA) of Rivers State, Nigeria. The Kingdom was a primordial African sovereign state of the Ijaw ethnic nationality, the fourth largest ethnic nationality or group in Nigeria. Bonny Kingdom is made up of many village communities and its capital city is Grand Bonny (variously called Grand Bonny City, Grand Bonny Island Community, Grand Bonny Island, and Bonny Island, Okoloama: 'curlew town'/'land of curlew birds']), which is also the headquarters of OLGA. ${ }^{2}$ The Kingdom is a strategically located Ancient Trading State (also called 'City-State') of the Niger Delta region. ${ }^{3}$

The Kingdom was founded before or about AD 1,000. ${ }^{4}$ Its Founding Ancestors were blood descendants of their common progenitor (Ebeni), who hailed from the Ebeni-toru area of ancestral Ijaw (Ijo), specifically from the Isedani Lineage of Okoloba in Kolokuma, in present-day Kolokuma-Opokuma Local Government Area (LGA) of Bayelsa State. The four leaders of the Founding Ancestors were Alagbariya (alias Kala-Beni ['Junior Ebeni']), his elder brother (Opuamakuba), his younger brother (Asimini) and their cousin (Ndoli-Okpara). Among these Ancestors were the blood descendants of Aboriginal Prince Kongo, who were also blood descendants of Ebeni. ${ }^{5}$

The above-stated four leaders of the Founding were the Premier Monarchs of the Kingdom. ${ }^{6}$ In Ibani, the word 'King' ('Monarch') is known as Amanyanabo, meaning 'owner of the land' (and, in effect, 'all the territories of the Kingdom'). ${ }^{7}$ Nevertheless, the Premier Monarchs only owned the Kingdom along with the rest of the Founding Ancestors or Founding Group of the Kingdom. In other words, the actual owners of the entire land and all the territories of the Kingdom are collectively its Founding Ancestors.

Considering that Bonny Kingdom was one of the Ancient Ijaw Trading States of the Niger Delta region, the other Ancient Ijaw Trading States are Opobo Kingdom, which emerged in 1869/70 from the Kingdom), Kalabari (New Calabar), Okrika and Nembe (Brass). These Ancient Ijaw Trading States, along with the Efik (Old Calabar) and Itsekiri (Warri) Trading States are known as Ancient Niger Delta Trading States. ${ }^{8}$ Ancient Grand Bonny Kingdom was the economic and political centre of the Ancient Niger Delta region and a significant symbol of African civilisation, before the creation of Opobo Kingdom out of it in 1870 and the eventual evolution of modern Nigeria in $1914 .^{9}$

The core social system and pivot of life and society at large in Ancient Grand Bonny Kingdom is the ward, lineage or house system. ${ }^{10}$ Consequently, the first wards, lineages or houses of the Kingdom were those of the Founding Ancestors and their blood descendants. ${ }^{11}$ From earliest times, the Kingdom was comprised of a homogenous blood-related Ijaw kindred group. The people of the kingdom remained homogenous until about the $18^{\text {th }}$ Century AD, when foster descendants of the Kingdom and their houses, which were created from then onwards, became members of the Kingdom. The period when the Kingdom was made up of its homogenous Ijaw group of

\footnotetext{
${ }^{1} \mathrm{UN}$, 'We Can End Poverty: Millennium Development Goals and Beyond' < https://www.un.org/millenniumgoals/>; World Health Organization, 'Millennium Development Goals (MDGs)' $<$ https://www.who.int/topics/millennium development goals/about/en/>; UN, 'Sustainable Development Goals Knowledge

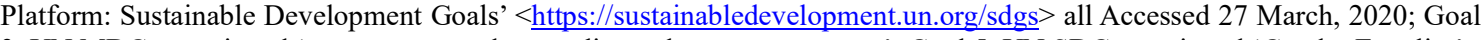
3, UN MDGs, captioned 'to promote gender equality and empower women'; Goal 5, UN SDGs captioned 'Gender Equality'. ${ }^{2}$ E. J. Alagoa and A. Fombo (n6), vii-viii and 3-4.

${ }^{3}$ K. O. Dike, Trade and Politics in the Niger Delta 1830-1885: An Introduction to the Economic and Political History of Nigeria (Greenwood Press 1981); G. I. Jones, The Trading States of the Oil Rivers: A Study of Political Development in Eastern Nigeria (Oxford University Press 1963/James Currey Publishers 2000); Encyclopaedia Britannica, 'Bonny: Nigeria'

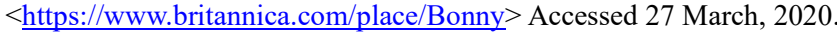

${ }^{4}$ E. J. Alagoa and A. Fombo (n6), 5.

${ }^{5} \mathrm{Ibid}, 3-5$.

${ }^{6} \mathrm{Ibid}, 3-8$.

${ }^{7}$ Ibid, 6.

${ }^{8}$ K. O. Dike (n9); E. T. Bristol-Alagbariya (n4), 106 and 109; Bonny Kingdom Historical Society, The History of Bonny (Bonny Kingdom Historical Society 2011), 17-20.

${ }^{9}$ K. O. Dike (n9), 31; E. T. Bristol-Alagbariya (n4), 109; Federal Republic of Nigeria, Nigeria at 50: A Compendium: The Official and Authoritative Book about Nigeria (Published on the Golden Jubilee Independence Anniversary www.1stoctober.com Publishing 2010), 33.

${ }^{10}$ E. J. Alagoa and A. Fombo (n6), 45, 49, 60-67.

${ }^{11}$ G. I. Jones (n9), 198; E. T. Bristol-Alagbariya (n4), 107-108.
} 
people witnessed the reign of the Kingdom's first twelve Monarchs. These Monarchs were Ndoli-Okpara, Opuamakuba, Alagbariye (Alagbariya) and Asimini. Others were Edimini, Kambasa, Kumalu, Opu Dappa, Amakiri, Appia, Wari and Awusa (Halliday or Halliday-Awusa). During the reign of King Halliday-Awusa, the population of the Kingdom had become heterogeneous; nevertheless, Monarchs of the Kingdom to present-times continue to remain blood descendants of its Founding Ancestors. ${ }^{1}$

Although distinct from those of several authors, we wish to rely on the list of Bonny Kingdom Monarchs recorded by E. J. Alagoa and A. Fombo and the programme of the $20^{\text {th }}$ Coronation Anniversary of His Majesty, Dr Edward Asimini William Dappa Pepple, wherein the Monarchs of the Kingdom are, so far, twenty three in number. These are Ndoli-Okpara, Opuamakuba, Alagbariye (Alagbariya) and Asimini. Others are Edimini, Kambasa, Kumalu, Opu Dappa, Amakiri, Appia, Wari and Awusa (Halliday or Halliday-Awusa). The rest are Perekule, Adum-Fubara, Adum-Opubu (Opubo), Adumtaye-Bereibibo, William Dappa Pepple, Dapuye-Fubara, George Oruigbi Pepple, Secondus George Pepple, Eugene William Dappa Pepple, Captain Opuada Secondus Pepple and Edward Asimini William Dappa Pepple. ${ }^{2}$ In this context of the list of kings considered here, Queen Kambasa, the spotlight of this study, was the sixth Monarch of the Kingdom.

\section{Natural Law and its Inherent Natural Right to Succession in Primordial Grand Bonny Kingdom}

Precisely, natural law theory of law presupposes the divine origin of law and rulership (governance) in society. ${ }^{3}$ The natural law school of thought (which is often distinguished from the positivist school of law or positive law theory $)^{4}$ posits that moral principles, rules and standards should or ought to be characteristically embedded in laws governing human societies, which include Bonny Kingdom. Natural law relates to leadership (especially political leadership, namely governance), based on the divine roots and characteristic features of natural law, which features include the virtues of God such as love, truth, righteousness, goodwill, selflessness, benevolence, transparency and accountability, as well as moral (ethical) behaviours of humans, such as fair-play, integrity, humility and commitment to duty. ${ }^{5} \mathrm{By}$ and large, natural law promotes everything rational (reasonable) and good (intelligibly good) as against all that is irrational (unreasonable) evil (intelligibly not good). ${ }^{6}$ It promotes sound deductive reasoning. ${ }^{7}$

Inherent in natural law are the concepts of natural rights ${ }^{8}$ and natural justice. ${ }^{9}$ Natural rights include the natural right to succession, such as succession to leadership positions like chieftaincy and kingship positions. It is on this note that ascension of Princess Ediminiba Kambasa to the exalted leadership position of kingship in Bonny Kingdom, due to her birth right as a blood descendant-female of one of the Founding Ancestors of the Kingdom, namely Premier King Asimini, is being considered. ${ }^{10}$

\footnotetext{
${ }^{1}$ E. J. Alagoa and A. Fombo (n6), 89, captioned 'King List'; Programme of the $20^{\text {th }}$ Coronation Anniversary of His Majesty, Dr Edward Asimini William Dappa Pepple, III, CON, JP, Perekule XI, Natural Ruler and Amanyanabo of Grand Bonny Kingdom, 9, entitled 'List of Bonny Monarchs'; c/f M. A. G. Leonard, The Lower Niger and Its Tribes (Frank Cass \& Co. 1968), 47, also captioned 'Kings of Bonny'

${ }^{2}$ Ibid.

${ }^{3}$ C. F. Alford (n1); Stanford Encyclopedia of Philosophy (n1).

${ }^{4}$ It is on this note that scholars often distinguish natural law from positive law and positive law theory, which considering manmade law as the command of a sovereign to his/her subjects, a contravention of which attracts punitive measures in the form of sanction, damages and admonition, among other consequences. R. Pound, 'Theories of Law' [1912] 22 (2) Yale Law Journal, 114-150; J. B. Murphy, The Philosophy of Positive Law: Foundations of Jurisprudence (Yale University Press 2005); T. Abate, 'Major Theories of Law' <https://www.abyssinialaw.com/about-us/item/479-major-theories-of-law $>$; Law Teacher, 'Legal Positivism' $<$ https://www.lawteacher.net/free-law-essays/jurisprudence/legal-positivism.php $>$; Legal Dictionary, 'Definition of Positive Law' https://legaldictionary.net/positive-law/; all Accessed 27 March, 2020.

${ }^{5}$ A. Gomez-Lobo, Morality and the Human Goods: An Introduction to Natural Law Ethics (Georgetown University Press 2001); J. D. Breshears, Natural Law: The Moral Foundation for Social and Political Civility (CentrePointe Publishing 2016); M. H. Kramer, Where Law and Morality Meet (Oxford University Press 2004); C. E. Rice, 50 Questions on the Natural Law: What It Is and Why We Need It (Ignatius Press 1999); Holy Bible, Philippians 4:8-9.

${ }^{6}$ J. Finnis, 'Natural Law and Legal Reasoning' [1990] 38 (1) Cleveland State Law Review, 1-14; C. F. Alford (n1); Stanford Encyclopedia of Philosophy (n1).

${ }^{7}$ E. H. Levi, An Introduction to Legal Reasoning (University of Chicago Press 2013); S. J. Burton, An Introduction to Law and Legal Reasoning (Aspen Publishers 2007);

${ }^{8}$ J. Finnis $(2011[\mathrm{n} 2])$.

${ }^{9}$ L. L. Weinreb, Natural Law and Justice (Harvard University Press 1990); J. C. H. Wu, Fountain of Justice: A Study in the Natural Law (Sheed \& Ward 1955); J. B. Gest, 'Fountain of Justice' [1956] 2 (3) The Catholic Lawyer, 267-270; O. B. Olukayode, 'An Appraisal of the Impact of Natural Law on Contemporary Legal Systems' [2018] 69 Journal of Law, Policy and Globalization, 46-53.

${ }^{10}$ J. Finnis (2011 [n2]).
} 
3.1. Natural Right of Succession to Leadership, Particularly Kingship in Primordial Grand Bonny Kingdom

The right to assume leadership, leadership positions, especially kingship, in primordial Grand Bonny

Kingdom is, first and foremost, the inalienable natural right of the Founding Ancestors of the Kingdom. ${ }^{1}$ The Founding Ancestors, led by the Four Founding Fathers, Patriarchs and Premier Monarchs (Ndoli-Okpara, Opuamakuba, Alagbariya and Asimini), are those who have a direct God-given right to leadership positions, particularly the position of kingship in the Kingdom.

By virtue of natural right and its inherent principle of succession, the natural right of the Founding Ancestors to assume leadership positions in the Kingdom became the right of the blood descendants of the Founding Ancestors. Along with the position of High-Priest, while some of the Founding Ancestors became the Premier Monarchs of the Kingdom, other leading members of the Founding Ancestors became the next category of rulers of the Kingdom known as Amadapu. On this note, the preceding work to this study states that during the era of the Founding, Aboriginal and Premier Monarchs, there were three principal classes of persons and/or office or title holders, namely (i) the Amanyanabo, (ii) the High-Priest of Ikuba (who, the Amanyanabo chiefly consulted and predominantly relied upon for advice and direction and thus was always in dialogue, agreement and understanding with the Amanyanabo), and (iii) the Amadapu, who were the subordinate rulers to the Amanyanabo, as component lineage heads and/or district rulers. Regents were and also remain known in Ibani as 'Amadapu'. The preceding work also highlights that these three principal rulers of the Kingdom constituted the Ibanise KoromaTaduapu Kubiri, which means 'Council of the Founders (Ancient Landmarks) of the Kingdom'. The preceding work highlights that members of the Ibanise KoromaTaduapu Kubiri governed the Kingdom by engaging the rest of their aboriginal kindred group in the affairs of the Kingdom. To this end, members of the Ibanise KoromaTaduapu Kubiri listened to the 'voices of reason' of the rest of the homogenous aboriginal kindred group of the Kingdom, and thereby ensured unanimous decision-making and decision-implementation processes as well as the discharge of responsibilities in the Kingdom. Classical examples of the discharge of responsibilities during the era of the Founding Ancestors were the surprising, overwhelming, fundamental, painful and supreme human sacrifices, namely the blood sacrifices of Aboriginal Virgin Crown Princess Osunju Alagbariya and Virgin Crown Princess Ogbolo Asimini, to the deities of the land and sea within the Kingdom, for the peace, development, growth, survival and sustenance of the Kingdom.

Aboriginal Virgin Crown Princess Osunju Alagbariya was sacrificed to the land deities to obtain good drinking water in Bonny and for peace in the Kingdom. Aboriginal Virgin Crown Princess Ogbolo Asimini was accordingly offered as sacrifice to deities of the sea, for the widening of the Bonny River, and thereby boosted external relations, particularly external trade and commerce between Portugal and Bonny Kingdom, which relations are still ongoing for the benefit of the modern Nigeria. By virtue of natural law and natural right to succession and inheritance, these two Aboriginal Virgin Crown Princesses, could have succeeded their fathers in particular, the rest of the four Premier Monarchs and entire Founding Ancestors, as Monarchs of the Kingdom.

After the era of the Founding Ancestors of the Kingdom, the right of succession to leadership and its accompanying discharge of duties and responsibilities naturally fell on their children and their subsequent blood descendants (both males [Aseme-Oyiapu ('men of aristocratic-nobility or aristocratic-birth')] and females [AsemeEremapu ('women of aristocratic-nobility or aristocratic-descent']). ${ }^{2}$ This was how succeeding High-Priests, Monarchs (Amanyanapu) and Amadapu of the Kingdom emerged or where appointed to occupy their respective positions of apex leadership in the Kingdom. With regard to kingship, this was how the second and third categories of Monarchs identified in the previous study became Monarchs of the Kingdom. The previous work highlights that throughout Bonny Kingdom's history, only blood descendants of the Founding Ancestors, particularly blood descendants of the four Premier Monarchs, have become Monarchs of the Kingdom. It is on this note that this study would proceed to focus on the ascension of Aseme-Orubo (Princess) Ediminiba Kambasa to the exalted leadership position of kingship in Bonny Kingdom.

\subsection{Natural Right of Blood Descendant-Females of the Founding Ancestors of Bonny Kingdom to Leadership Positions: Spotlight on Queen Kambasa}

We recall that the previous work to the study and the preceding sub-heading hereof demonstrate how the Founding Ancestors of Bonny Kingdom truly, respectfully, fairly and harmoniously enjoyed their natural right to leadership and accordingly shared duties and responsibilities among themselves. Truth, respect for each other, fairplay and harmony could thus be considered as watchwords between and among the Founding Ancestors of the Kingdom.

Aseme-Orubo (Princess) Ediminiba Kambasa was the daughter of King Edimini, son of Premier King Asimini, younger brother of Premier Kings Alagbariya and Opuamakuba, who are cousins to Premier King Ndoli-

\footnotetext{
${ }^{1}$ L. Strauss (n2).

${ }^{2}$ H. T. Terry, 'Legal Duties and Rights' [1903] 12 (4) The Yale Law Journal, 185-212; D. Lyons, 'The Correlativity of Rights and Duties' [1970] 4 (1) Noûs, 45-55.
} 
Okpara. ${ }^{1}$ The granddaughter of Premier King Asimini, Aseme-Orubo Ediminiba Kambasa, was on the instruction of her father (King Edinimi), given to Prince Opoli of Azuogu of the then Ndoki country, for marriage, so as to maintain the Ndoki hinterland market of Bonny Kingdom. Princess Kambasa was however unhappy about her father's directive, as she was in love with a Bonny Elder and nobleman, Biriye, of Peterside. Consequently, after proceeding to Azuogu to live with Prince Opoli, Princess Kambasa sought to and did return to Bonny. It was during this period that Prince Opoli sent a boat-load of manila to King Edimini, as dowry for Princess Kambasa. The King rejected the dowry and left the boat containing same to sink at where it was harbouring at the Bonny waterfront. Prince Opoli reacted against the attitude of King Edimini towards him, by stopping Bonny traders from having access to his Ndoki-home Bonny hinterland market. ${ }^{2}$

As her marriage with Prince Opoli was not consummated in accordance with Bonny custom, Princess Kambasa finally returned to Bonny. During this period, Prince Opoli had problems with his people and he abandoned his home-town (Azuogu) with some of his followers, and came to Bonny Kingdom, where he sought for refuge. He settled at part of present-day's Aganya section of Bonny Island Community (Okolomama), which was at the time nicknamed Opolikiri, meaning 'settlement of Opoli'. ${ }^{3}$

After returning to Bonny and upon the demise of her father (King Edimini), Princess Ediminiba Kambasa succeeded him by becoming the next Monarch of Bonny Kingdom. ${ }^{4}$

\section{Legacies of Queen Kambasa}

This aspect of the study is aimed at considering certain legacies of Queen Kambasa, such as the natural right of her blood descendants to become Monarchs of Bonny Kingdom, and the GTG features of her reign concerning how she strengthened GTG in the Kingdom. However, before then, it is important to take an overview of the importance and role of women in primordial Bonny Kingdom, in relation to the ascension of Princess Kambasa to the exalted position of kingship in the Kingdom.

\subsection{Overview of the Importance and Role of Women in Primordial Grand Bonny Kingdom}

From time immemorial, during the primordial era of Bonny Kingdom, when the Kingdom was a homogenous group of its Ijaw aboriginal stocks (comprised of the Founding Ancestors and later on their successive blood descendants), the people of the Kingdom did not discriminate against their female folks. Thus, primordial Bonny people were gender friendly, and as such practised gender equity and equality, even concerning nondiscrimination of their female folks from assuming leadership positions, which include the position of kingship. A crystal example or clear testimony of aboriginal Bonny Kingdom's nature of gender friendliness, is the ascension of Princess Kambasa to the apex position of leadership, namely to become the Monarch of the Kingdom. At the time, the leadership of the Kingdom was engaging the people, which include the ordinary citizens, both males and females, in public sector governance (in the course of governing the Kingdom), which deals with the affairs of the Kingdom.

In the process, rights and privileges as well as duties and responsibilities of primordial Bonny Kingdom were borne by both male and female folks of the Kingdom. Thus, for example, prominent daughters of the Founding Ancestors, such as Legendary Aboriginal Virgin Crown Princesses Osunju Alagbariya and Ogbolo Asimini, who, by virtue of right, could have succeeded their fathers, were made to bear the burdens of the people and entire Kingdom. These Aboriginal Virgin Crown Princesses were thus sacrificed to the deities of the land and those of the sea respectively, to foster peace, development, growth, survival and sustenance of the Kingdom. In many ramifications, these Princesses were considered to have carried the crucial and inevitable burdens of the Kingdom. The Kingdom began to stand and survive on the shed blood of these Legendary Aboriginal Virgin Crown Princesses. Based on the blood sacrifices of these two Legendary Aboriginal Virgin Crown Princesses, ongoing petroleum resources development operations in Bonny Kingdom are blood-oil and blood gas operations. ${ }^{5}$ For so bearing the surprising, painful, crucial, fundamental, supreme and inevitable burden of the post-settlement era of the Kingdom, these two Princesses were revered by the Founding Ancestors. These Virgin Crown Princesses were so revered because of the general belief and conviction that they saved the Kingdom from declining or even going into extinction. The Founding Ancestors celebrated them and immortalise their names as formidable Ancient Landmarks of the Kingdom and bedrocks of its continuing civilisation as a primordial sovereign state. In many

\footnotetext{
${ }^{1}$ E. J. Alagoa and A. Fombo (n6),8; Bonny Kingdom Historical Society (n14), 53.

${ }^{2}$ E. J. Alagoa and A. Fombo (n6),8; Bonny Kingdom Historical Society (n14), 53-54.

${ }^{3}$ Bonny Kingdom Historical Society (n14),54.

${ }^{4}$ E. J. Alagoa and A. Fombo (n6),8; Bonny Kingdom Historical Society (14), 53.

${ }^{5}$ E. D. Dublin-Green and R. A. Cross Brown, 'Disbursement of Shell's N2.45bn Stirs Crisis in Bonny...', being a response of the Duawaris (Association of the Founding \& Aboriginal royal houses) of Grand Bonny Kingdom, dated August 19, 2019, to the Editor, Guardian Newspapers of Nigeria (Guardian Nigeria), in reaction to the Guardian Newspaper publication on the above-stated subject, dated August 4, 2019, 3.
} 
ramifications, these Princesses were considered to have carried the crucial and inevitable burdens of the Kingdom. Customarily and traditionally, they were and still remain revered as physical and spiritual custodians of the Kingdom. Therefore, Legendary Aboriginal Virgin Crown Princesses Osunju Alagbariya and Ogbolo Asimini shall remain revered in the annals of the history and entire life and times of the Kingdom.

Furthermore, to prove that the Founding Ancestors and their blood descendants did not discriminate against their daughters, the voice of reason of Princess Okuru was respected and hearkened onto by her uncle, King Halliday-Awusa, during the critical period of the Bonny-Andoni seven years' war, consequent upon which Perekule succeeded Halliday-Awusa as Monarch.

Also, it is a time immemorial custom of Bonny Kingdom that daughters of the Kingdom, who are not married, inherit from the families of their fathers. No wonder therefore that, Princess Kambasa was considered a legitimate and credible daughter of her father, King Edimini, who succeeded him, when her marriage to Prince Opoli of Azuogu of Ndoki was considered invalid, as same was not consummated in accordance with Ibani custom. Consequently, upon the demise of King Edimini, Princess Ediminiba Kambasa contended with her male cousins and co-kingship (Amanyanaboship) aspirants and outsmarted them by seizing the Odu (kingship staff of office) used by her father, and thus succeeded him, as the Monarch. E. J. Alagoa and A. Fombo give account of Princess Ediminiba Kambasa's ascension to the position of kingship in Bonny Kingdom, in the following words:

... Kambasa, daughter of King Edimini, son of Asimini. She got accepted as queen by seizing an ivory tusk [staff of office:Odu] bearing the name of her predecessor (apparently an essential royal emblem). She thus became notable in Bonny history for being the first and only woman to occupy the throne. ${ }^{1}$

From the foregoing brief analyses and illustrations of the exemplary life of Queen Kambasa, the great important, significant and sometimes exceptional roles, as well as legitimacy of women and womanhood in primordial Grand Bonny Kingdom up to date are thus so clear and cannot be over-emphasised. ${ }^{2}$

Certainly, women should no longer be subjugated or marginalised arbitrarily in contemporary Bonny Kingdom, especially against the aboriginal custom of the Kingdom and the dictates of natural law, ${ }^{3}$ as universally acknowledged, agreed and respected in the parlance of human rights, human rights law and practice. ${ }^{4}$ It is good and crucial for Bonny Kingdom to appreciate efforts of the UN system on women and the girl child, particularly in the context of the increasingly evolving, overarching and overwhelming frameworks of sustainable development (SD) law and regulatory practices towards gender equality. ${ }^{5}$

\subsection{Legacies of Queen Kambasa's Reign Regarding Natural Right of Succession to the Position of Kingship}

By virtue of natural law and its accompanying natural right, the legacies and lessons of Queen Kambasa's reign include the fact that her blood descendants have been emerging as Monarchs of Bonny Kingdom. Precisely, this demonstrates the God-given (divine) natural right of succession of Queen Kambasa's blood descendants to succeed her. Thus, for instance, Queen Kambasa's immediate successor was Kumalu, whom she begat with Prince Opoli. In turn, King Kumalu was succeeded by his son, Opu Dappa. Accordingly, King Opu-Dappa was succeeded by his son, Amakiri. King Amakiri was succeeded by his brother Apia, who was also the son of King Opu-Dappa, grandson of Queen Kambasa. King Apia was succeeded by his son, Wari. Thereafter, Awusa (Halliday or Halliday-

${ }^{1}$ E. J. Alagoa and A. Fombo (n6), 8; G. Finapiri, Forgotten Heroes of Grand Bonny (CSS Press 2001) v, 10; N. C. Ejituwu and A. O. I. Gabriel, Woman in Nigerian History: The Rivers and Bayelsa States Experience (Onyoma Research Publications 2003), 42.

2 E. T. Bristol-Alagbariya, 'The Role of Women in the Wellbeing of Society', being a paper delivered at a Symposium Organised by the Old Girls Association of Government Girls Secondary School (GGSS), Finima, Bonny, with the Theme 'Celebrating 40 Years of Educating the Girl-Child (The First Ever All Old Girls Homecoming (1981 - 2016)', Friday, October 20, 2017, @ the GGSS, Finima, Bonny.

${ }^{3}$ R. J. Berry, Inheritance and Natural History (William Collins 2013); J. Finnis (2011 [n2]); C. F. Alford (n1).

${ }^{4}$ Articles 2 and 3, Universal Declaration of Human Rights (UDHR), 1948; Articles 2 and 18 (1) and (2) of the African Charter on Human and Peoples' Rights (Ratification and Enforcement) Act, No.3 1983, Cap A9 LFN 2004 (Cap 10 LFN 1990); V. E. Onuoha, 'The Nigerian Society and Issues of Justice for Women [2008] 9 (1) Nigeria Education Law Journal (NELJ), 1-15, particularly 1 and $13-15$.

${ }^{5}$ UN General Assembly (UNGA), 'Convention on the Elimination of All Forms of Discrimination against Women (CEDAW), by virtue of the UNGA Resolution 34/180 of 18 December 1979 $<$ https://www.un.org/en/development/desa/population/migration/generalassembly/docs/globalcompact/A_RES_34_180.pdf> ; UN, ' UN Women' <https://www.unwomen.org/en>; Women's International League for Peace and Freedom, 'Outcome of CEDAW Review of Nigeria: More Action Needed to Implement the WPS Agenda' $<$ https://www.wilpf.org/outcome-of-cedawreview-of-nigeria-greater-action-needed-to-implement-the-wps-agenda/> all Accessed 27 March, 2020; Women Aid Collective (WACOL) for Nigeria NGO COALITION on CEDAW Report, CEDAW and Accountability to Gender Equality in Nigeria: A Shadow Report (Women's Aid Collective 2008); Goal 3, UN Millennium Development Goals (UN MDGs), captioned 'to promote gender equality and empower women' towards promoting gender equality and empowering women; Goal 5, UN Sustainable Development Goals (UN SDGs), captioned 'Gender Equality' towards achieving gender equality and empowering all women and girls. 
Awusa) succeeded King Wari. King Halliday-Awusa was the grandson of Queen Kambasa. King Halliday-Awusa was in turn succeeded by his cousin, Perekule. Perekule was the grandson of Queen Kambasa, through Papanye (Papabara), who in turn begat Siriye. Princess Kambasa begat Papanye (Papabara) out of wedlock with a Bonny nobleman, Biriye. Considering that Prince Opoli knew that the biological father of Papanye was Biriye, in Ibani language, Papabara was interpreted to mean 'love's labour lost'.

The rest of the Monarchs of Bonny Kingdom after King Perekule up to the incumbent Monarch (King Edward Asimini William Dappa Pepple) are blood descendants of King Perekule. Among them, King AdumtayeBereibibo is of mixed blood; being a blood descendant of Premier King Alagbariya (through AdumtayeBereibibo's father, Amadabo Adapa, who crowned King Perekule), as well as grandson of King Perekule (through Perekule's daughter, Princess Adumta). King Adumtaye-Bereibibo was thus a blood descendant of Premier King Alagbariya, as well Premier King Asimini (through Queen Kambasa to Princess Adumta [daughter of King Perekule]).

Accordingly, it is the legacy of Queen Kambasa that each of the blood descendants of her so far seventeen successors, have natural right to assume the throne of kingship (Amanyanaboship) in Bonny Kingdom.

By and large, whereas it is true that the seventeen blood descendants and successors of Queen Kambasa became Monarchs of Bonny Kingdom by virtue of their respective natural right of succession (through the Queen), it is a greater truth that the Queen and her successors became Monarchs on the basis of their respective natural right of succession, which is derived from Premier King Asimini (the Queen's grandfather), and accordingly the natural right of succession of the four Premier Monarchs (Ndoli-Okpara, Opuamakuba, Alagbariya and Asimini) and then above all, the natural right to succession of the entire Founding Ancestors of the Kingdom. On the whole, it is the Founding Ancestors that have direct God-given natural right to ownership of the Kingdom, including its kingship position, as well as its commonwealth and entire heritage. Also, given the immense spiritual and utmost traditional importance of the personal, painful, supreme, unparalleled, unsurpassed and overwhelming blood sacrifices of Virgin Crown Princesses Osunju Alagbariya and Ogbolo Asimini, it remains clear that their respective lineages could not be undermined with regard to producing candidates for kingship in the Kingdom; this is particularly the case by virtue of natural law and its accompanying natural right of succession to leadership positions, and moreover that in law, duties and responsibilities have their corresponding rights. ${ }^{2}$ All in all, each blood descendant of the Premier Monarchs and the rest of the Founding Ancestors of Bonny Kingdom has natural right to become Monarch in the Kingdom. ${ }^{3}$

Nevertheless, there can only be one Monarch of the Kingdom at a time; this is where the natural law theory of the divine origin of law and leadership (governance) ${ }^{4}$ in human societies comes into play as well as the issue of competing natural rights. It is even more crucial to consider the favour of God Almighty, from Whom natural law and leadership originate, as well as being the Spiritual and thus Ultimate Maker of Monarchs. It is well known in divine parlance that God Almighty rules over the affairs of humans and thereby chooses and ordains whosoever He wants as the Monarch ${ }^{5}$ of any Kingdom or society practising the Monarchical system of governance.

Natural rights inherent in natural law are therefore somehow unimpeachable by manmade law, namely positive law. ${ }^{6}$ At best, any arbitrary manmade law or rule whatsoever may only prevail momentarily and not indefinitely. Natural right to leadership positions may however be subject to particular prescribed form(s) of succession and will of God Almighty, Who is the divine originator of law, divine and earthly institutions ${ }^{7}$ of governance and governments in all the nooks and crannies of the world (including the traditional government of Bonny Kingdom, at the apex of which is Kingship [the Monarchy]).

\footnotetext{
${ }^{1}$ E. J. Alagoa and A. Fombo (n6), 8; Bonny Kingdom Historical Society (n14), 53-54.

${ }^{2}$ H. T. Terry (n29); D. Lyons (n29).

${ }^{3}$ J. Finnis (2011 [n2]); C. F. Alford (n1); L. Strauss (n2); Y. Olomojobi, Human Rights and Civil Liberties in Nigeria: Discussions, Analyses, and Explanations (Princeton \& Associates Publishing Co. 2018), 2; D. Ashdown, The Royal Line of Succession: The British Monarchy from Egbert AD 802 to Queen Elizabeth II (Pitkin Publishing 1999); A. Weir, Britain's Royal Families: The Complete Genealogy (Vintage 2008); R. J. Berry (n37); I. Sagay, Nigerian Law of Succession: Principles, Cases, Statutes and Commentaries (Malthouse Press 2006); R. Kerridge, Parry and Kerridge: The Law of Succession (Sweet \& Maxwell 2016); J. A. Borkowski, Textbook on Succession (Oxford University 2005).

${ }^{4}$ C. Roosevelt, The Science of Government, Founded On Natural Law (Nabu Press 2014); P. E. Sigmund, Natural Law in Political Thought (University Press of America 1981).

${ }^{5}$ Holy Bible, Psalm 11:4; 24:1; 47: 2 and 8; 103:19; 113:5; 115:3; Daniel 4:17 and 25. Psalm 24:1, states that 'the earth is the LORD's, and the fullness thereof, the world and all who dwell therein; 1 Corinthians 10:26, also provides that '.. the earth is the Lord's, and the fullness thereof'; Psalm 103:19, expresses that 'the LORD has established His throne in heaven, and His kingdom rules over all'; Psalm 47: 8, asserts that 'God reigns over the nations; God is seated on His holy throne'; Psalm 11:4, which testifies that the LORD is in His holy temple; the LORD is on His heavenly throne. His eyes are watching closely; they examine the sons of men.

${ }^{6}$ C. F. Alford (n1); Stanford Encyclopedia of Philosophy (n1).

${ }^{7}$ Holy Bible, Psalm 11:4; 24:1; 47: 2 and 8; 103:19; 113:5; 115:3; Daniel 4:17 and 25.
} 


\subsection{Queen Kambasa's Administration: Strengthening of Good Traditional Governance (GTG)}

Queen Ediminiba Kambasa learnt good leadership attributes from her forebears (the Founding Ancestors, especially the Premier Monarchs]) of Primordial Bonny Kingdom. She also inherited masculine traits from them, particularly her father, King Edimini. She strengthened GTG, and thereby elevated the status of Bonny Kingdom further, as an Ancient City-State of the Niger Delta and a primordial African sovereign entity.

Queen Kambasa organised her youngster-blood relatives, who admired her collaborative and receptive style of leadership. She did so, by pooling them together in an equitably widespread form, as a set of royal assistants and bodyguards. ${ }^{1}$ She legitimately fortified her reign by her broadminded attitude of fairly engaging her cousins and co-contenders of the throne, among who were her immediate subordinates (Amadapu), in decision-making and overall service to the Kingdom. As such, it is obvious that she never arrogated natural right to kingship to herself, as if that right belonged to her alone. By such broadminded and other similar measures of fair-play, her administration was rationally all-inclusive, rather than being misguidedly selective and discriminatory among the homogenous (blood-related) kindred group of the Kingdom.

She maintained respect for service to the people and the kingdom through responsible stewardship among her blood relatives, who were nobles, particularly the priests and her immediate subordinates (Amadapu). In the course of making and implementing decisions, she meticulously listened and hearkened onto the voices of reason among the rest of the blood-related kindred group of the Kingdom. Therefore, she was greatly admired and respected as an efficient ruler, and her orders were appreciated and obeyed by the people.

Regarding cultural displays, Queen Kambasa organised Bonny's national club of mask dancing artists, Ogbokoroama (Ibanise Ogbokoroma) group. ${ }^{2}$ This group seasonally played masquerades in the Kingdom. Certainly, cultural displays, as a form of arts and culture flourished greatly and thus attracted tourists, including the Kingdom's Niger Delta neighbouring Kingdoms, communities and areas, as well as its hinterlands trading counterparts, apart from Western European traders and visitors to Bonny Kingdom, who were excited to watch African cultural displays.

In terms of foreign policy and relations, Queen Kambasa positioned Bonny Kingdom on the path of prosperity, sustainable growth, development and advancement. ${ }^{3}$ For instance, she sent intelligent and brave citizens of the Kingdom who embarked on great expeditions to discover hitherto unknown places. She preserved the accounts of such expeditions by writing them on clay. ${ }^{4}$

Trade and commerce flourished in Bonny Kingdom during the reign of Queen Kambasa. She was a wealthy Monarch, who fostered and ensured the wellbeing of her people and the entire Kingdom. She derived happiness and joy in the prosperity of the people and her entire Kingdom. As such, the people enjoyed her reign. Particularly, her cousins, who contended the position of kingship with her, also enjoyed her reign and became satisfied with her public administrative prowess, such as her amiable hospitality and subtle but frank diplomatic approach to issues. As Queen Kambasa transformed these cousins of her's into her passionate admirers, they promoted her administrative style and legitimacy in office as their Amanyanabo.

Queen Kambasa was also a Matriarch-Military General of primordial Grand Bonny Kingdom. She demonstrated military bravery and might in course of the Kingdom's encounter with Opuoko and Kalaoko of Ogoniland, during her reign. G. Finapiri succinctly describes this encounter in the following manner:

... She set out on the expedition for which she is best known in history - the annexation of Opuaoko by the biggest army that Ibani had ever seen. All the resources of the Kingdom were used to collect men and materials for the expedition.

Her reign was short in Bonny but her passage has left marks for all time [s]. By diplomacy and by the exercise of those masculine traits, which she had inherited from her father, Kambasa raised Bonny to be a powerful city state in the Eastern Niger Delta.... When she was told of the killings of the Ibani people by the Ogoni of Opuoko, who were believed to have been great oppressors of Ibani in their time of migration, her proud heart caught fire. She raised an army of Ibani and fell upon Opuoko. She was a tigress in her period of revenge and sought by savagery to settle scores, the only method of retaliation known to the age. As a Queen, she proved that in matters such as rulership and toughness, a determined woman could outsmart a man. The slaughter was horrible in keeping with the pagan times. But the agonising lesson she taught was never forgotten. Opuoko was shown that wronged weaknesses may [give] rise to maddened strength and become an instrument of terrible retribution. ${ }^{5}$

The foregoing may suffice as an appropriate testimony of Queen Ediminiba Kambasa's military might and bravery,

\footnotetext{
${ }^{1}$ E. J. Alagoa and A. Fombo (n6),8; N. C. Ejituwu and A. O. I. Gabriel (n35), 42.

${ }^{2}$ Ibid.

${ }^{3}$ C/f T. Jackson, Prosperity without Growth?: The Transition to a Sustainable Economy (Sustainable Development Commission 2009); T. Jackson, Prosperity without Growth: Economics for a Finite Planet (Earthscan 2011).

${ }^{4}$ E. J. Alagoa and A. Fombo (n6),8; G. Finapiri (n35), 10.

${ }^{5}$ G. Finapiri (n35), 10-11.
} 
as Amanyanabo of primordial Grand Bonny Kingdom.

Also, while eulogising Ediminiba Kambasa's effectiveness as Amanyanabo of Bonny Kingdom, especially with regard to her intelligent manner of handling domestic affairs, as well as her shrewd and skilful form of foreign policy and swift, strategic and efficient style of foreign relations, N. C. Ejituwu and A. O. I. Gabriel state as follows:

Kambasa is remembered in Bonny history as one of the most effective rulers both in domestic and foreign relations. ${ }^{1}$

Amanyanabo Kambasa tremendously imbibed, immensely exhibited and considerably practised traditional government social responsibility (TGSR) ingrained in good traditional governance (GTG). Surely, she was a good and uncommon leader as well as a great achiever, like her contemporary, Sarauniya (Queen) Amina of the City-State of Zazzau (one of the original seven Hausa City-States and present-day city of Zaria in Kaduna State, northern Nigeria). ${ }^{2}$ Certainly, like Queen Amina of Zaria, Queen Kambasa was a Matriarch as well as an Iron-Lady of GG in primordial Grand Bonny Kingdom, who strengthened GTG in the Kingdom. ${ }^{3}$

\section{Conclusion}

So far, the study has discussed the history of oil-rich Ancient Grand Bonny Kingdom, simply called as Grand Bonny Kingdom or Bonny Kingdom, as a primordial sovereign state of the Niger Delta and African civilisation. It gave an overview of the origin of public sector governance from the beginning of the Kingdom, within the rubrics of the house system, by the Founding Ancestors (led by the Founding Fathers, Patriarchs and Premier Monarchs) of the Kingdom. The work establishes that although the Kingdom's form of traditional government is hierarchical in nature, during the era of the Founding Ancestors, decision-making and decisionimplementation processes were collectively discharged among the ranks and files of homogenous population of the Kingdom. This underscores the great importance, exceptional roles and legitimacy of women in the Kingdom, more so when the two of the Kingdom's Legendary Virgin Crown Princesses, Osunju Alagbariya and Ogbolo Asimini, were sacrificed to the Kingdom's deities of the land and sea, for the peace, development, growth, survival and sustenance of Bonny Kingdom, and by extension modern Nigeria, which is benefiting from the sacrifice, in the course of ongoing external relations, particularly external trade in petroleum resources through the Bonny Atlantic coast. Besides, based on the bedrock of good governance (GG) and good traditional governance (GTG), premised on responsible stewardship to the people and entire Kingdom, by the Founding Ancestors, led by the Premier Monarchs of the Kingdom, their successors like Queen Kambasa imbibed and practised GG.

Queen Kambasa was enthroned as Monarch due to birth right, arising from natural law and natural right to succession and inheritance, which include succession to leadership positions, which right is inherent in natural law. It is indeed Queen Kambasa's legacy that her blood descendants are still ruling Bonny Kingdom as Monarchs. By and large, the classical example of the reign of Queen Kambasa demonstrates that her blood descendants as well as other blood descendant of the Premier Monarchs and entire Founding Ancestors have legitimate right, in natural law, to rule the Kingdom as Monarchs. In other words, under divine natural law and natural right, the pool of succeeding Monarchs of Bonny Kingdom are blood descendants of the Founding Ancestors, especially the blood descendants of the Premier Monarchs of the Kingdom.

It may be added that the reign of Queen Kambasa evidences the great importance, exceptional roles and legitimacy of women in primordial Grand Bonny Kingdom. Consequently, the study admonishes and recommends that women should no longer be subjugated or marginalised arbitrarily in contemporary Bonny Kingdom, especially against the aboriginal custom of the Kingdom and the dictates of natural law, and as universally acknowledged, agreed and respected in the parlance of human rights, human rights law and practice. It is good and crucial for Bonny Kingdom to appreciate efforts of the UN system on women and the girl child, particularly in the context of the increasingly evolving, overarching and overwhelming frameworks of SD law and regulatory practices towards gender equity and equality. With the classic example of the reign of Queen Kambasa, this study has gone a long way to substantiate and justify the role and importance of Bonny women and to recommend that these women should no longer be relegated in the affairs of contemporary Bonny Kingdom.

Queen Kambasa administered Bonny Kingdom in a broadminded manner by fairly engaging her cousins and co-contenders of the throne of kingship in decision-making and overall service to the Kingdom; as such, it was obvious that she truly demonstrated that natural right to kingship never belonged to her alone. This broadminded manner of her administration strengthened and legitimised her reign and popularity in the Kingdom

\footnotetext{
${ }^{1}$ N. C. Ejituwu and A. O. I. Gabriel (n35), 42 and 97.

${ }^{2}$ B. Awe (ed), Nigerian Women in Historical Perspective (Sankor/Bookcraft 1992), 11-23; Encyclopaedia Britannica, 'Zaria: Historical Kingdom and Province, Nigeria' $\leq$ https://www.britannica.com/place/Zaria-historical-kingdom-and-provinceNigeria>; BBC News, 'Queen Amina: Nigerian Warrior Queen' <https://www.bbc.com/news/av/world-africa44888718/queen-amina-nigerian-warrior-queen> both Accessed 27 March, 2020.

${ }^{3}$ B. Awe (ed) (n53), 25-35; N. C. Ejituwu and A. O. I. Gabriel (n35), 6, 42 and 97.
} 
and beyond.

In particular, Kambasa was an extraordinary Matriarch, a very brave, courageous and uncommonly admired Amanyanabo; a visionary foreign policy and foreign relations strategist, astute political economy tactician and an incomparable Military General; indeed an Amazon Field Marshal of primordial Grand Bonny Kingdom. By and large, Queen Kambasa imbibed, exhibited and practised TGSR ingrained in GTG, particularly GG. Although she reigned for a short period, she clearly was passionately loved, very well respected and greatly revered by her people. She was a highly dignified and rare symbol of good leadership of the Kingdom and thus an image of a very responsible and respected woman and womanhood of Ancient Niger Delta and African civilisation. Comparable to her contemporary, Queen Amina of Zaria, Queen Kambasa remains in the annals of African history as a unique personality of universally enviable African culture, arts and tradition and an exemplary Monarch. Like Queen Amina, Queen Kambasa was a Matriarch as well as an Iron-Lady of GG in Grand Bonny Kingdom. Certainly, like her contemporary, Queen Amina of Zaria, Queen Ediminiba Kambasa of Bonny Kingdom was an exceptionally great African Monarch of all times, who may be showcased as a classic example of a highly dignified, socially responsible and magnificent calibre of womanhood in African history and civilisation.

Fundamentally, this study remarks that Queen Kambasa promoted and ensured the wellbeing of the people and entire Kingdom. She derived happiness and joy in the prosperity of the people and entire Bonny Kingdom, which included her cousins who contended the position of kingship with her. As such, many of such her cousins enjoyed her reign, became satisfied with her good administration and thereby turned into her passionate admirers. A crucial endeavour subsequent Monarchs of the Kingdom - especially the blood descendants of Queen Kambasa - should make, reminiscent of her life and times, particularly to promote her legacies, is to practise traditional governance social responsibility (TGSR), inherent in good traditional governance (GTG), in the Kingdom, and thereby derive joy and happiness in the wellbeing of the people and entire Kingdom.

All in all, it may be simply, precisely and squarely stated that good governance (GG), in particular GTG, premised on the characteristic features of natural law, is an attribute that Queen Kambasa learnt from her forebears (the Founding Ancestors of Bonny Kingdom and her predecessor-Monarchs, especially the four Premier Monarchs (Ndoli-Okpara, Opuamakuba, Alagbariya and Asimini). Among these Premier Monarchs, King Asimini was Queen Kambasa's grandfather.

The attributes of natural law, its characteristic features associated with GG as well as the ethical relationship of law to GG practised by the Premier Monarchs and well imbibed and practised by their immediate successors, such as Queen Kambasa, may be mentioned. They include love, truth, goodwill, selflessness, benevolence, responsible stewardship, humility, an such moral (ethical) norms as integrity, fair-play, commitment to duty, sincerity of purpose, transparency, accountability, harmonious and unanimous decision-making and decision-implementation processes, which amounted to partnership in governance, towards the good and overall wellbeing of the people and the entire Bonny Kingdom.

It is therefore Queen Kambasa's profile, legacy and to her credit, that GTG continues in Ancient Grand Bonny Kingdom, and we recommend it, at least, to please God Almighty, from Whom natural law originates and Who is the Maker, Chief Executive, Principal Overseer and Ultimate Auditor General of all leaders (including sovereign and non-sovereign rulers) as well as governments around the world. We also recommend that Queen Kambasa's GTG legacy should prevail in favour of Bonny women and particularly so, to boost gender equity and equality in oil-rich and Christianised Bonny Kingdom.

\section{References}

Alagoa E. J. and Fombo A., A Chronicle of Grand Bonny (Ibadan University Press 1972/Onyoma Research Publications 2001), vii-viii, 3-10, 24-27, 45, 49, 60-67, 89.

Alford C. F., Narrative, Nature, and the Natural Law: From Aquinas to International Human Rights (Palgrave Macmillan 2010).

Animashaun T. O. G. and Oyeneyin A. B., Law of Succession, Wills and Probate in Nigeria (MIJ Publishers 2002).

Ashdown D., The Royal Line of Succession: The British Monarchy from Egbert AD 802 to Queen Elizabeth II (Pitkin Publishing 1999).

Awe B. (ed), Nigerian Women in Historical Perspective (Sankor/Bookcraft 1992), 11-23 and 25-35.

Berry R. J., Inheritance and Natural History (William Collins 2013).

Bonny Kingdom Historical Society, The History of Bonny (Bonny Kingdom Historical Society 2011), 17-20, 53- 
54.

Borkowski J. A., Textbook on Succession (Oxford University 2005).

Breshears J. D., Natural Law: The Moral Foundation for Social and Political Civility (CentrePointe Publishing 2016).

Bristol-Alagbariya E. T., Governance Towards Sustainable Development in Nigeria: The Role of Strategic Assessment of Decisions \& Actions (Centre for Energy, Petroleum \& Mineral Law \& Policy [CEPMLP]/Dundee University Press [DUP] 2013), 44-49 and 286.

Bristol-Alagbariya E. T., Participation in Petroleum Development: Towards Sustainable Community Development in the Niger Delta (CEPMLP/DUP 2010), 106-109.

Dike K. O., Trade and Politics in the Niger Delta 1830-1885: An Introduction to the Economic and Political History of Nigeria (Greenwood Press 1981), 24, 31-32.

Ejituwu N. C. and Gabriel A. O. I., Woman in Nigerian History: The Rivers and Bayelsa States Experience (Onyoma Research Publications 2003), 6, 42 and 97.

Faseke M., The Nigerian Woman: Her Economic and Socio-Political Status in Time Perspective (Agape Publications 2001).

Federal Republic of Nigeria, Nigeria at 50: A Compendium: The Official and Authoritative Book about Nigeria (Published on the Golden Jubilee Independence Anniversary www.1stoctober.com Publishing 2010), 33.

Finnis J., 'Natural Law and Legal Reasoning' [1990] 38 (1) Cleveland State Law Review, 1-14.

Finnis J., Natural Law \& Natural Rights (Oxford University Press 2011).

Gest J. B., 'Fountain of Justice' [1956] 2 (3) The Catholic Lawyer, 267-270.

Gomez-Lobo A., Morality and the Human Goods: An Introduction to Natural Law Ethics (Georgetown University Press 2001).

Jackson T., Prosperity without Growth: Economics for a Finite Planet (Earthscan 2011).

Jackson T., Prosperity without Growth?: The Transition to a Sustainable Economy (Sustainable Development Commission 2009).

Jones G. I., The Trading States of the Oil Rivers: A Study of Political Development in Eastern Nigeria (Oxford University Press 1963/James Currey Publishers 2000).

Finapiri G., Forgotten Heroes of Grand Bonny (CSS Press 2001) v, 10- 11.

Kerridge R., Parry and Kerridge: The Law of Succession (Sweet \& Maxwell 2016).

Kramer M. H., Where Law and Morality Meet (Oxford University Press 2004).

Leonard, M. A. G., The Lower Niger and Its Tribes (Frank Cass \& Co. 1968), 23-24, 47.

Lyons D., ‘The Correlativity of Rights and Duties’ [1970] 4 (1) Noûs, 45-55.

Murphy J. B., The Philosophy of Positive Law: Foundations of Jurisprudence (Yale University Press 2005).

Olomojobi Y., Human Rights and Civil Liberties in Nigeria: Discussions, Analyses, and Explanations (Princeton \& Associates Publishing Co. 2018), 2.

Olukayode O. B., 'An Appraisal of the Impact of Natural Law on Contemporary Legal Systems' [2018] 69 Journal of Law, Policy and Globalization, 46-53. 
Onuoha V. E., 'The Nigerian Society and Issues of Justice for Women [2008] 9 (1) Nigeria Education Law Journal (NELJ), 1-15.

Osuji C., Nigerian Women in Politics: Past, present and Future: A Motivational Bookfor Office Seekers; Those Occupying Leadership Positions and for Every Woman (Opinion Research and Communications 2011).

Pound R., 'Theories of Law' [1912] 22 (2) Yale Law Journal, 114-150.

Rice C. E., 50 Questions on the Natural Law: What It Is and Why We Need It (Ignatius Press 1999).

Roosevelt C., The Science of Government, Founded On Natural Law (Nabu Press 2014).

Sagay I., Nigerian Family Law: Principles, Cases, Statutes \& Commentaries (Malthouse Press 1999).

Sagay I., Nigerian Law of Succession: Principles, Cases, Statutes and Commentaries (Malthouse Press 2006).

Sigmund P. E., Natural Law in Political Thought (University Press of America 1981).

Strauss L., Natural Right and History (Charles R. Walgreen Foundation Lectures) (University of Chicago Press 1965).

Terry H. T., 'Legal Duties and Rights' [1903] 12 (4) The Yale Law Journal, 185-212

Weinreb L. L., Natural Law and Justice (Harvard University Press 1990).

Weir A., Britain's Royal Families: The Complete Genealogy (Vintage 2008).

Wu J. C. H., Fountain of Justice: A Study in the Natural Law (Sheed \& Ward 1955). 